\title{
Paging KIng Solomon: Towards Allowing ORgan DONATION FROM ANENCEPHALIC INFANTS
}

\author{
Fazal Khan, M.D., J.D. ${ }^{*}$ and Brian Lea**
}

\section{TABLE OF CONTENTS}

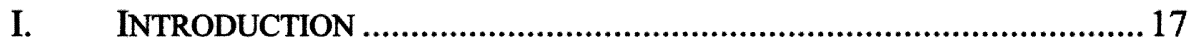

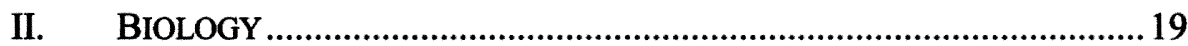

III. THE POTENTIAL USE OF ANENCEPHALIC INFANTS AS ORGAN DONORS FOR OTHER CHILDREN ................................................21

IV. THE DEAD DONOR RULE: LEGAL RESTRICTIONS ON ANENCEPHALIC

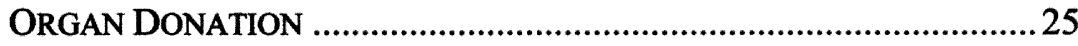

V. RETHINKING THE DEAD DONOR RULE: POTENTIAL SOLUTIONS TO A

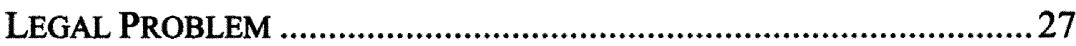

A. Complete Abandonment of the Dead Donor Rule .......................27

B. Argument That Anencephalic Children Never Possess Life....... 28

C. A Limited Approach Qualifying Anencephalic Infants as an Exception to The Dead Donor Rule ............................................. 32

VI. THE FEAR THAT SCIENTISTS WOULD INTENTIONALLY CREATE ANENCEPHALIC ORGAN DONORS .......................................................34

A. Scientists May Soon Possess the Ability to Intentionally Create Anencephalic Infants................................................................ 34

B. Proposed Legal Rules to Ensure the Integrity of the Anencephalic Organ Transplant Process .......................................................... 37

1. Criminalization of Intentional Creation of Anencephalic Human Beings ................................................................... 37

2. Imposition of Strict Liability for Anyone Transplanting Organs From Intentionally Created Anencephalic Infants.. 40

VII. A POSSIBLE SOCIOECONOMIC IMPLICATION OF ANENCEPHALIC

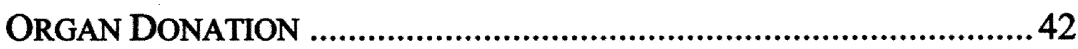

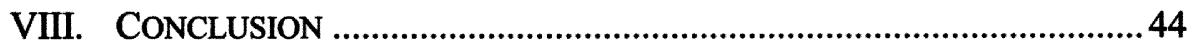

\section{INTRODUCTION}

In October of 1987, Canadian doctors artificially sustained the life of an anencephalic infant so that her organs could be transplanted into another child,

* Assistant Professor of Law, the University of Georgia School of Law; B.A. - University of Chicago; M.D. - University of Illinois College of Medicine; J.D. - University of Illinois College of Law.

** J.D. 2009, University of Georgia School of Law. 
touching off a fiery debate. ${ }^{1}$ At the request of her parents, doctors connected Baby Gabrielle, who was born missing most of her brain, to a respirator before flying her to Loma Linda, California, where her heart was transplanted into the world's youngest recipient of a heart transplant. ${ }^{2}$ While Baby Gabrielle's parents insisted that their daughter's organs be used in this manner and were presumably happy with the resulting transplant, one of Baby Gabrielle's doctors expressed qualms about his role in the saga. Almost immediately, a firestorm of debate ignited as parents of unborn children with anencephaly began offering their children's organs for use in similar procedures. ${ }^{3}$ Critics quickly began warning of slippery slopes and difficult moral questions. ${ }^{4}$ This continuing debate calls into question the medical propriety and the usefulness of current medical definitions of death. It also implicates even more fundamental issues, questioning what is required for a life to be considered fully human and also the nature and extent of respect, both legal and medical, warranted by such a life.

This Article attempts to demonstrate that organ donation from anencephalic infants can be both beneficial and morally justifiable. Section I discusses the biological and physical manifestations of anencephaly. Section II introduces the current need for infant organs for transplantation, the possibility that anencephalic organs could address some of that demand, and the basic ethical positions both for and against the allowance of anencephalic organ transplantation. Section III discusses the dead donor rule, the legal obstacle which currently makes anencephalic organ donation legally problematic. Section IV discusses possible legal approaches to permitting organ transplants from anencephalic donors: the abandonment of the dead donor rule would cause too many undesirable consequences; the classification of anencephalic infants as non-persons offends society's general ethical norms and creates slippery slope problems that are in the realm of possibility; however, the classification of anencephalic infants as persons born into a state of death permits anencephalic organ donation without denying anencephalic infants personhood status and opening Pandora's box. Section V lays out legal safeguards necessary to prevent the abuse of an anencephalic organ donation scheme in the event that mankind perfects its ability to intentionally create anencephalic human organ donors. Section VI addresses potential class-related social concerns posed by

1. Ellen Goodman, Is This Gift of Life Worth Price, CHIC. TRIB., Dec. 13, 1987, at 2.

2. Sandra Blakeslee, Baby Without Brain Kept Alive to Give Heart, N.Y. TimEs, Oct. 19, 1987, at A1 (describing the story of Baby Gabrielle and transplant recipient, Paul Holc).

3. See Sandra Blakeslee, Infant Transplant Program Is Halted to Reassess Issues, N.Y. TIMES, Aug. 20, 1988, at 17 (noting that, following Baby Gabrielle saga, "more than 200 parents and physicians representing parents inquired about the possibility of using such babies as organ donors" but that the program was suspended due to "medical, ethical, and emotional difficulties").

4. Peter Steinfels, Ideas \& Trends: Infant Organ Plan Ends; Brief Lives, Large Questions, N.Y. TIMES, Sept. 18, 1988, at 8 (noting that parents of unborn anencephalic infants "wanted to donate their newborns' hearts and livers to save the lives of other infants" while critics "loudly voiced fears that society was marching into a moral quagmire"). 
anencephalic organ donation while arguing that a facially-just transplant policy should not be tainted by independent social problems, such as lack of medical care for the poor. This Article concludes by advocating for the sake of infants in need of organ transplants a properly tailored transplant policy allowing parents of anencephalic infants to donate their children's organs for use in transplants.

\section{BIOLOGY}

Anencephaly, "generally defined as the congenital absence of skull, scalp and forebrain," has been described as a "nightmarish neural tube defect." This condition is "characterized by a lack of brain development above the level of the brainstem," and such children often lack a cerebrum, cerebellum, and bones of the skull. ${ }^{7}$ The cause of anencephaly remains a mystery to modern science, ${ }^{8}$ although there have been studies demonstrating that supplementation with folic acid prior to conception and during the early stages of pregnancy can decrease the chances that a child will be born with anencephaly.

Children suffering from anencephaly, sometimes defined as an "absence of the cerebral hemispheres" and occasionally involving malformation or absence of portions of the brain stem or spine, often possess a jarring appearance, as "the absent brain is sometimes replaced by malformed cystic neural tissue, which may be exposed or covered with skin." the newborn sufferer are brutal and swift, as there is "no way to save such a child, which in virtually all cases dies hours after birth." Anencephaly is easily diagnosed through amniocentesis and high-resolution ultrasonography, as the defect typically develops during the first two months of pregnancy. ${ }^{12}$ The diagnosis frequently results in the abortion of such infants, even in those countries

5. D. Alan Shewmon, Anencephaly: Selected Medical Aspects, HASTINGS CENTER REP., Oct.-Nov. 1988, at 11.

6. Graeme Stemp-Morlock, Pesticides and Anencephaly, 115 ENVTL. HeAlth PerSP. A78 (2007).

7. Sue A. Meinke, Anencephalic Infants as Potential Organ Sources: Ethical and Legal Issues, 12 SCOPE NOTES 1, 2 (1989), available at http://bioethics.georgetown.edu.

8. See Anencephaly-info, www.anencephalie-info.org (last visited Apr. 11, 2008) (follow link to "Frequent Questions") (noting that no one knows what causes anencephaly, yet stating that parents do not cause anencephaly).

9. See De Wals et al., Reduction in Neural-Tube Defects After Folic Acid Fortification in Canada, 357 NEw ENG. J. MED. 135 (2007) (noting that fortification of cereal products with folic acid in Canada decreased prevalence of neural tube defects, particularly where that prevalence was previously highest); see also Sandeep Grover \& Nitin Gupta, LithiumAssociated Anencephaly, 50 CAN. J. PSYCHIATRY 185, 185-86 (2005) (describing the anecdotal case of a pregnant woman with an anencephalic fetus who took lithium prior to conception).

10. The MERCK MANUAl of Diagnosis AND ThERAPY 2222 (Mark H. Beers \& Robert Berkow eds., Merck Research Laboratories 17th ed.1999) [hereinafter MERCK MANUAL].

11. Dena Kleiman, For a Catholic Doctor, A Crisis of Conscience, N.Y. TIMES, Apr. 22, 1987, at B1.

12. See MERCK MANUAL, supra note 10. 
where the procedures remains illegal. ${ }^{13}$ If not aborted, an anencephalic infant has a high probability of being stillborn; however, this fate is not certain. ${ }^{14}$

While one medical dictionary states that anencephaly "is incompatible with life," $" 15$ the fact remains that such infants do on occasion survive past birth to live, in the most basic sense of the word, for a brief period of time. ${ }^{16}$ Inevitably however, anencephaly results in death, as, while a brainstem alone can maintain the most basic life functions, termed the autonomic functions, for a short period of time, without the rest of the brain breathing fails sporadically, with these failures increasing in frequency until respiration ceases altogether. ${ }^{17}$ The only remaining question is how swiftly the child's death will come.

Even during their brief lives, anencephalic infants do not experience or interact with the world in a manner that corresponds with any common view of the human experience. Consciousness, in its most basic sense, is "the state or condition presupposed by any experience whatsoever."18 Anencephalic children are "by definition permanently unconscious because they lack the cerebral cortex necessary for conscious thought," rendering them rather similar to those in a persistent vegetative state. ${ }^{19}$ While lower brainstem functions, including "breathing, blood pressure, temperature, and neuroendocrine control," can continue for some period of time in the absence of a cerebrum, consciousness and cognition, "the earmarks of higher brain activity," require a functioning cerebrum. ${ }^{20}$ The lack of consciousness of anencephalic infants has major implica-

13. See Maria Cristina R. Guilam \& Marilena C.D.V. Corrêa, Risk, Medicine and Women: A Case Study on Prenatal Genetic Counseling in Brazil, 7 DEVELOPING WORLD BIOETHICs 78, 79 (2007) (noting that in Brazil abortion is a criminal offense, but that in cases of anencephaly and similar defects, social and even judicial opinion has been mixed).

14. Harold Chen, ATLAS of GenETIC Diagnosis AND CoUNSELING 721 (Humana Press 2006) (referring to anencephaly as the most severe of neural tube defects and noting its common association with stillbirth and death soon after birth).

15. TABER'S CYCLOPEDIC MEDICAL DICTIONARY 100 (17th ed. 1993).

16. See First, Do No Harm, 122 COMMONWEAL 4 (1995) (observing that anencephalic babies, when they survive birth, usually die within a few hours or days of their birth); see also MERCK MANUAL, supra note 10, at 2222 (stating anencephalic infants are not helped by treatment and are either stillborn or die within days or weeks of birth). But see Tracy K. Koogler, Benjamin S. Wilfond \& Lainie Freedman Ross, Lethal Language, Lethal Decisions, 33 HASTINGS CENTER REP. 37, 38 (2003) (describing a case involving an anencephalic infant who survived for approximately two and one half years due to the effects of aggressive care and mechanical breathing assistance provided when her mother refused to terminate such care).

17. See J.L. Peabody, J.R. Emery \& S. Ashwal, Experience with Anencephalic Infants as Prospective Organ Donors, 321 NEw ENG. J. MED. 344(1989) (describing the method of death typical of anencephalic infants who survive live birth and stating that such death renders their organs unsuitable for transplantation by time legal requirements for death are satisfied).

18. Bjorn Merker, Consciousness Without a Cerebral Cortex: A Challenge for Neuroscience and Medicine, 30 BEHAV. \& BRAIN SCI. 63, 63-64 (2007) (further defining consciousness as "the 'medium' of any and all conscious experience").

19. In re T.A.C.P., 609 So. 2d 588, 590 (Fla. 1992), as reprinted in JANET L. DOLGIN \& LOIS L. SHEPHERD, BIOETHICS AND THE LAW 838, 839 (Aspen 2005).

20. David Randolph Smith, Legal Recognition of Neocortical Death, 71 CORNELL L. REV. 850, 857 (1986). But see President's Comm'N For tHe STUdy of ETHICAL Problems IN MEDICINE AND BIOMEDICAL AND BEHAVIORAL RESEARCH, DEFINING DEATH: A REPORT ON THE 
tions for the debate surrounding their use as sources of transplant organs for other infants.

\section{THE POTENTIAL USE OF ANENCEPHALIC INFANTS AS ORGAN DONORS FOR OTHER CHILDREN}

While modern technology has vastly increased mankind's ability to successfully transplant organs, the unfortunate fact remains that fewer donors exist than potential recipients of transplants. ${ }^{21}$ This quantitative discrepancy between those who need organs and the number of organs available for transplantation is magnified when one focuses specifically on children, as a "severe shortage of transplantable organs exists for infants and children with life-threatening cardiac, renal, and hepatic disease." ${ }^{22}$ When this shortage of organs for children in need of transplants is coupled with the fact that many of the organs needed, such as livers, kidneys, and hearts, "cannot be stored or banked" for later use, it becomes apparent that, under the existing system, the demand for organs for transplantation into children will continue to outpace the available supply.

The medical community possesses the technology necessary to use anencephalic infants as a source of organs for transplantation into other children. ${ }^{24}$ While anencephalic children lack a brain, the rest of their organs typically develop normally, making them physically suitable for use in transplants. ${ }^{25}$ The way in which an anencephalic infant dies, however, typically destroys the suitability of that infant's organs for transplantation into other infants; as the anencephalic baby's respiratory processes repeatedly lapse due to its lack of higher brain function, its "oxygen-starved organs are so severely damaged that they are no longer suitable for transplantation." ${ }^{, 26}$ Medical professionals, however, can

MEDICAL, LEGAL, AND ETHICAL IsSUES IN THE DETERMINATION OF DEATH 15 (1981) [hereinafter DEFINING DEATH] (noting that consciousness may not be so easily compartmentalized, that interactions between cerebral cortex and brainstem may create consciousness, and that "the 'higher brain' may well exist only as a metaphorical concept, not in reality").

21. See Charles C. Dunham IV, "Body Property": Challenging the Ethical Barriers in Organ Transplantation to Protect Individual Autonomy, 17 ANNALS HEALTH L. 39 (noting that "not every person who needs an organ transplant will receive one"); see also United Network for Organ Sharing, http://www.unos.org/ (last visited Feb. 15, 2008) (stating that on February 8, $2008,98,080$ patients waited for only 13,224 donor organs).

22. Robert D. Truog, Abstract, Anencephalic Newborns: A Source of Transplantable Organs?, 5 J. INTENSIVE CARE MED. 82 (1990), available at http://jic.sagepub.com/cgi/ content/abstract $/ 5 / 2 / 82$..

23. Howard S. Schwartz, Bioethical and Legal Considerations in Increasing the Supply of Transplantable Organs: From UAGA to "Baby Fae," 10 AM. J.L. \& MED. 397, 398 (1985).

24. See supra notes 1-2 and accompanying text.

25. See Jeffrey R. Botkin, Anencephalic Infants as Organ Donors, 82 Pediatrics 250, 251 (1988) (noting the rate of malformation of anencephalic infant's organs exceeds that of the general population, "but not to a degree that would preclude their use in transplantation"). But see Winnie Wai-Ying Li et al., The Eyes of Anencephalic Babies: A Morphological and Immunohistochemical Evaluation, 117 INT'L J. NEUROSCIENCE 121, 129-32 (2007) (observing that the eyes of three Chinese anencephalic neonates revealed few retinal abnormalities, but that the same eyes exhibited degeneration in corneas, irises, and lenses).

26. Jay A. Friedman, Taking the Camel by the Nose: The Anencephalic as a Source for 
avoid this problem by artificially maintaining the life of an anencephalic newborn through the use of a respirator and other modern technology so that the infant's organs can be removed while the anencephalic child is still living, or, more accurately, breathing thereby preserving the infant's organs for transplantation. $^{27}$

Such methods have received support from some parents of anencephalic children. ${ }^{28}$ In addition, the American Medical Association ("AMA") approved the harvesting of organs from anencephalic infants in $1995 .^{29}$ As represented by the story of Baby Gabrielle, ${ }^{30}$ such measures could give the parents of anencephalic children the ability to pull some sense of purpose out of the tragedy of giving birth to a child with anencephaly by granting another child the possibility of a full life. Supporters of anencephalic organ donation generally argue that anencephalic organ donation not only provides life to infants in need of organs at little or no expense to the donor, but also provides a sense of meaning to the emotionally distraught parents of an anencephalic child; such donation is, therefore, under a hedonistic utilitarian calculus," "morally justified because it produces the greatest good for the greatest number of people." 32 Not everyone, however, views harvesting the organs of children with anencephaly in such a positive light.

The AMA withdrew its report proclaiming that the harvesting of organs from anencephalic children was intrinsically moral in the face of widespread criticism in both society and the general medical community. ${ }^{33}$ Critics typically

Pediatric Organ Transplants, 90 CoLuM. L. Rev. 917, 924 (1990).

27. Loma Linda University Medical Center, the hospital which performed the transplant involving Baby Gabrielle, developed the first protocol addressing the use of anencephalic infants as a source of organs for transplantation. Under that protocol, anencephalic infants were to be kept on life support for up to a week, at which point, if they were not yet brain dead, the support would be removed and they would be allowed to die naturally. ANENCEPHALIC ORGAN DONATION COMMITTEE OF LOMA LINDA UNIVERSITY MEDICAL CENTER, CONSIDERATIONS OF ANENCEPHALIC INFANTS AS ORGAN DONORS: A WORKING DOCUMENT 3-4 (1987) (on file with authors).

28. Shewmon, supra note 5, at 15 (observing that "[a]lthough there is [sic] no hard data on the proportion of brain-dead children whose parents are willing to donate their organs, the experience in UCLA's pediatric intensive care unit approximates 75 percent" and postulating that when narrowed to anencephalics, this percentage will approach two-thirds).

29. See generally Council on Ethical and Judicial Affairs, Am. Med. Ass'n, The Use of Anencephalic Neonates as Organ Donors, 273 JAMA 1614 (1995) (basing new policy on grounds that anencephalic infants have no interest in life and that the purposes of the "dead donor rule" were therefore not served by forbidding harvesting of organs from anencephalic newborns).

30. See supra notes 1-4 and accompanying text.

31. Utilitarianism is commonly associated with two British philosophers, Jeremy Bentham and John Stuart Mill, and "is referred to as a consequentialist or teleological approach to morals because actions are judged by their results" rather than the principles of the actor. JANET L. DOLgIN \& LoIs L. SHEPHERD, BIOETHICS AND THE LAW 14-15 (Aspen Publishers 2005). A utilitarian outlook views an act as justified if it results in a net increase of happiness or pleasure. Id.

32. Beth Brandon, Anencephalic Infants as Organ Donors: A Question of Life or Death, 40 CASE W. RES. L. REV. 781, 800-01 (1990).

33. DOLGIN \& SHEPHERD, supra note 31, at 153 (observing that while the issue itself has 
base their argument against the use of the organs from anencephalic infants for transplantation on the sanctity-of-life doctrine. This theory tends to disregard the quality of life issues frequently cited in utilitarian arguments, instead focusing on the belief that all human life is sacred even those burdened with the most severe handicaps known to medicine and that every life should therefore be sustained. ${ }^{34}$ The sanctity-of-life doctrine can often be found entwined with arguments citing Immanuel Kant's Categorical Imperative, which "calls for humans to be treated as ends in themselves, and never solely as a means to an end." 35 Finally, those opposing the use of anencephalic infants as organ donors argue that to proceed toward such a policy is to risk falling down a slippery slope of ever worsening consequences. ${ }^{36}$

The use of anencephalic infant organs for transplantation implicates two "very influential normative ethical views" philosophical debates: utilitarianism is often advocated by those in favor of the use of anencephalic organ donors, whereas Kantianism, expressing a deontological viewpoint, is often embraced by those opposing the practice. ${ }^{38}$ Given the chasm that exists between these divergent points of view, the level of consensus necessary to change the law regarding organ donation by anencephalic infants seems unlikely to exist in the near future. ${ }^{39}$ Supporters of anencephalic organ donation can nevertheless make a strong argument that such donation satisfies both utilitarian and Kantian normative requirements.

receded in importance due to pre-birth diagnosis and abortion of many anencephalic infants, the issue remains important due to its influence on debates concerning patients in persistent vegetative states).

34. See Lois Shepherd, In Respect of People Living in a Permanent Vegetative StateAnd Allowing Them to Die, 16 HEALTH MATRIX 631, 677 (2006) (listing the sanctity-of-life doctrine as among arguments advanced by those who support feeding of patients in persistent vegetative states in absence of patient's wishes).

35. John D. Arras \& Shlomo Shinnar, Anencephalic Newborns as Organ Donors: A Critique, 259 J. AM. MED. Ass'N. 2284, 2284 (1989).

36. See Lisa E. Hanger, The Legal, Ethical, and Medical Objections to Procuring Organs From Anencephalic Infants, 5 HEALTH MATRIX 347, 356 (1995) (noting that "[c]onsidering anencephalic infants 'dead' or 'close enough to death' instills in the public a fear that other individuals very near death also will be declared dead and will be killed for the sake of procuring their organs").

37. ANDERs NoRDgren, Responsible Genetics: The Moral Responsibility of GeNeticists for tHe CONSEQuences OF Human GeNeTics Research 25 (Kluwer Acad. Publishers 2001).

38. See supra notes 31-34 and accompanying text.

39. The practical reality is that whether or not the organs of anencephalic donors are utilized depends entirely on the laws regarding organ donation. While bioethical and philosophical arguments will necessarily be used by whatever side eventually wins the debate over this issue, the arguments in and of themselves will not have a practical effect without a change in the actual law, and "until there is a consensus that these standards should be changed, anencephalic infants cannot and should not be used as sources for donor organs." Jennifer S. Bard, The Diagnosis is Anencephaly and the Parents Ask About Organ Donation: Now What? A Guide for Hospital Counsel and Ethics Committees, 21 W. NEW ENG. L. REv. 49, 94 (1999). See generally David Orentlicher, Commentary, Organ Retrieval from Anencephalic Infants: Understanding the AMA's Recommendations, 23 J.L. MED. \& ETHICS 401 (1995) (reinforcing the idea that law trumps ethics opinions and pointing out that an ethics opinion regarding anencephaly expressly declared that its implementation was subject to governing law). 
Making use of the organs of anencephalic infants for transplantation purposes is consistent with a strictly utilitarian calculus because other than the donor, who some argue possesses no or only a slight interest in the matter, "all human parties concerned stand to receive great benefit," including the transplant recipient, the transplant recipient's parents, and the parents of the donor. ${ }^{41}$ While some argue that such a utilitarian conclusion fails to take into account the potentially far reaching consequences of endorsing transplants from anencephalics and thereby risks a rapid descent down a slippery slope, such a risk can be avoided by framing any justification for harvesting anencephalic organs in the most narrow way possible to maintain a clear limiting principle on the logic involved. ${ }^{42}$ Transplantation from anencephalic infants is, therefore, consonant with a raw utilitarian perspective, as "[u]tilitarianism demands that the greatest number of persons benefit from the anencephalic infant's organs, even if it means changing the present legal definition of death to include infants with anencephaly." $" 43$

The greatest challenge to the use of organs donated by anencephalic infants lies in the form of accusations that such a practice would violate Kantianism, a "bedrock principle of Western ethics," by failing to treat such children as an end in themselves and denying them their humanity. ${ }^{44}$ Some answer this assertion with the claim that "[r] espect for the essential worth of life . . . is not an absolute value in the sense of overriding all other values" enough balancing of utilitarian factors in favor of allowing anencephalic organ donation could override Kantian concerns about the practice. Such an approach, however, unconvincingly attempts to sidestep the Kantian issue by appealing to a utilitarian formulation. Others argue that Kantian logic does not apply in the case of anencephalic infants, as Kant "did not have in mind nonself-aware humans."

Similarly, some argue that anencephalic infants should qualify medically

40. The absent or low interest in life of an anencephalic infant has also been cited as a justification for refusing any treatment beyond palliative care to anencephalics. Such an argument asserts that provision of care to anencephalic infants is both quantitatively and qualitatively futile. "Quantitatively, it is futile because an anencephalic . . . will die soon no matter what physicians do. Qualitatively, it is futile because they will never be conscious or enjoy any form of human experience." E. Haavi Morreim, Futilitarianism, Exoticare, and Coerced Altruism: The ADA Meets Its Limits, 25 SETON HALL L. REV. 883, 886 (1995).

41. Ethics and Social Impact Committee, Anencephalic Infants as Sources of Transplantable Organs, HASTINGS CENTER REP., Oct.-Nov. 1988, at 29.

42. See infra notes 83-88 and accompanying text.

43. Joseph N. Harden, The "Gift" of Life: Should Anencephalic Infants Die to Serve Noble Goals?, 27 CuMB. L. REV. 1279, 1302 (1996).

44. J.C. Willke \& Dave Andrusko, Personhood Redux, HASTINGs CENTER REP., Oct.-Nov. 1988 , at 31 .

45. Harden, supra note 43, at 1309.

46. J. Steven Justice, Casenote, Personhood and Death-The Proper Treatment of Anencephalic Organ Donors Under the Law: In re T.A.C.P., 609 So. $2 d 588$ (Fla. 1992)., 62 U. CIN. L. REV. 1227, 1261 (1994). 
as being "dead," ${ }^{, 47}$ and thus Kantian principles would not bar harvesting organs from a non-living infant. Making this point could move society closer to the consensus required to change the current state of the law, thereby opening the channels through which much needed organs could be acquired from infants with anencephaly for use in children needing transplants. A proper legal approach to anencephalic organ transplants must adhere to and reinforce society's ethical values without upsetting beyond the extent necessary the current legal approach to organ transplantation.

\section{THE DEAD DONOR RULE: LEGAL RESTRICTIONS ON ANENCEPHALIC ORGAN DONATION}

The "dead donor rule" states simply that "it is immoral to kill patients by taking their organs," until that patient has been declared legally dead. ${ }^{49}$ How doctors apply this rule in a practical setting has obvious implications for the effectiveness of transplant procedures. As any transplant surgeon could tell you, "we cannot transplant organs that have begun to decompose or grow necrotic; thus, we must determine the death of the human being very quickly when organ donation is desired." 50 Thus, the definition of death used by the medical professional making the determination of death becomes extremely important in a transplant setting.

The common law generally defined death according to "two easily observable and universally familiar touchstones, namely, a permanent absence of bloodflow and breathing." traditionally widely accepted as a bright-line rule has come into disfavor as it "minimizes the possibilities of successful organ transplantation by discouraging physicians, due to their fear of possible criminal or civil liability, from removing the donor's organs until after respiration and heartbeat have ceased and the organs have begun to deteriorate." of death, an anencephalic child undoubtedly qualifies as alive until complete respiratory cessation, at which point the child's organs would be useless for transplantation. ${ }^{53}$ Such a result would preclude the use of anencephalic infants

47. See infra notes 89-102 and accompanying text.

48. Elyssa R. Koppelman, The Dead Donor Rule and the Concept of Death: Severing the Ties That Bind Them, 3 AM. J. BIOETHICS 1 (2003) (noting further that the dead donor rule attempts to balance deontological and utilitarian concerns).

49. See generally Robert M. Arnold \& Stuart J. Youngner, The Dead Donor Rule: Should We Stretch It, Bend It, or Abandon It?, 3 KENNEDY INST. ETHICS J. 263 (1993) (discussing the dead donor rule, including critiques of the rule and its future).

50. James Dubois, Abstract, Avoiding Common Pitfalls in the Determination of Death, 23 ISSUES L. \& MED. 204, 204 (2007).

51. Jason L. Goldsmith, Wanted! Dead and/or Alive: Choosing Among the Not-SoUniform Statutory Definitions of Death, 61 U. MIAMI L. REV. 871, 879 (2007).

52. Thomas R. Trenkner, Annotation, Tests of Death for Organ Transplant Purposes, 76 A.L.R.3d 913 (1977).

53. See D. Scott Bennett, Comment, Chimera and the Continuum of Humanity: Erasing 
as organ donors; however, cardiopulmonary failure no longer monopolizes the definition of death, as legislatures have taken measures to keep up with evolving medical knowledge of the dying process.

Most states have now adopted the Uniform Determination of Death Act (the "Act"), ${ }^{54}$ which specifies that an "individual who has sustained either (1) irreversible cessation of circulatory and respiratory functions, or (2) irreversible cessation of all functions of the entire brain, including the brain stem, is dead" and that such a "determination of death must be made in accordance with accepted medical standards." 55 While this statute allows death, defined in the United States as the "moment at which the bodies physiological system ceases to constitute an integrative whole," mon law cardiopulmonary fashion, the rule also incorporates an alternative method of determining death in the form of total or whole brain death. In other words, for the purposes of determining death under the Act, the "ability of other parts of the body to function via life support is not relevant if the brain has completely failed."57

The ability to define death as whole brain death has rendered organ transplantation much more feasible in many cases. If a patient fails a battery of tests designed to detect brainstem function and it is determined that the patient has no spontaneous ability to breathe, then the patient is declared dead, and, if an organ donor, "taken to the operating room for organ recovery and transplantation, while mechanical ventilation is continued and with the beating heart still perfusing the patient's organs." brain death standard satisfies the dead donor rule while allowing the donor's organs to be preserved for transplantation.

Unfortunately for children in need of organs, the neurological definition of death embraced in the Act does not apply easily to newborns in general and anencephalic infants in particular. To begin, doctors typically have great difficulty determining if brain death has occurred in newborn children since "infants may later develop brain functions that they do not have at birth,"59 a fact which has led some thinkers to call upon doctors to wait seven days before making a

the Line of Constitutional Personhood, 55 EMORY L.J. 347, 368 (2006) (observing that the common law definition of death does not include those with "total, irreparable loss of higherlevel brain function but with some continuing respiratory and cardiac functions").

54. See Jason M. Horst, The Meaning of "Life": The Morning-After Pill, the Question of When Life Begins, and Judicial Review, 16 TEX. J. WoMEN \& L. 205, 223-24 (2007) (arguing that states have passed the Uniform Determination of Death Act in an attempt to achieve universality).

55. UNIF. DETERMINATION OF DEATH ACT $§ 1$ (1980), 12A U.L.A. 386, § 1 (WEST 1980 \& SUPP. 2003).

56. DEFINING DEATH, supra note 20 , at 33.

57. Bennett, supra note 53 , at 369.

58. Robert D. Truog, Brain Death-Too Flawed to Endure, Too Engrained to Abandon, 35 J.L. MED. \& ETHICS 273, 273 (2007).

59. Joseph J. Volpe, Brain Death Determination in the Newborn, 80 PEDIATRICs 293, 294-95 (1987). 
determination of brain death in a newborn. ${ }^{60}$

To begin, doctors typically have great difficulty determining if brain death has occurred in newborn children since "infants may later develop brain functions that they do not have at birth," "61 a fact which has led some thinkers to call upon doctors to wait seven days before making a determination of brain death in a newborn. ${ }^{62}$ In addition to the problems inherent in making a neurological determination of death in a newborn, anencephalic newborns pose special difficulties under such a standard. A child with anencephaly, like a person in a persistent vegetative state, entirely lacks cognitive abilities, and yet nevertheless maintains spontaneous cardiac and respiratory function, at least sporadically, during his or her brief life. ${ }^{63}$ This maintenance of basic life functions, including respiratory functions, is due to the functioning of the brain stem in an anencephalic infant. ${ }^{64}$ Therefore, anencephalic infants do not meet the requirements of either prong of the Act; "while their brain stems function, they do not meet the legal standards for death" donors until their organs are too deeply damaged to be of use. Consequently, in order to enable the use of the organs of anencephalic infants, medicine and the law must embrace a new approach to the dead donor rule.

\section{RETHINKING THE DEAD DONOR RULE: POTENTIAL SOLUTIONS TO A LEGAL PROBLEM}

\section{A. Complete Abandonment of the Dead Donor Rule}

Some thinkers advocate that the dead donor rule should be abandoned and replaced with a regime in which "individuals who desire to donate their organs and who are either neurologically devastated or imminently dying should be allowed to donate their organs without first being declared dead." ${ }^{, 66}$ Those who

60. Task Force for the Determination of Brain Death in Children, Guidelines for the Determination of Brain Death in Children, 37 NEUROLOGY 1077, 77-78(1987).

61. Joseph J. Volpe, Brain Death Determination in the Newborn, 80 PEDIATRICs 293, 294-95 (1987).

62. Task Force for the Determination of Brain Death in Children, Guidelines for the Determination of Brain Death in Children, 37 NEUROLOGY 1077, 77-78 (1987).

63. See Multi-Soc'y Task Force on PVS, Medical Aspects of the Persistent Vegetative State-First of Two Parts, 330 N. ENG. J. MED. 1499, 1501-03 (1994) (listing forms of permanent unconsciousness, including persistent vegetative state, coma, end stages of degenerative neurological conditions, and anencephaly).

64. John-Anderson L. Meyer, " 'Tis a Consummation to Be Devoutly Wished:" Towards Consistency in End-of-Life Treatment Decisions for Comatose Adults and Imperiled Newborns, 10 Mich. ST. U.J. MED. \& L. 321, 335 (2006).

65. Mary Crossley, Infants with Anencephaly, the ADA, and the Child Abuse Amendments, 11 IsSUES L. \& MED. 379, 383 (1996) (noting that anencephalic infant is not dead until brain stem functions cease, but that natural death damages organs through process of oxygen deprivation).

66. Robert Truog \& Walter M. Robinson, Role of Brain Death and the Dead Donor Rule in the Ethics of Organ Transplantation, 31:9 CRITICAL CAREMED. 2391, 2391 (2003), available 
support the demise of the dead donor rule point to what they view as inherent flaws in the application of the rule, including the present inability to accurately assess total brain death and the disconnect between medical and popular definitions of death. ${ }^{67}$ Also, opponents of the dead donor rule claim that the rule fails to inquire into whether the potential donor is being respected as a person, focusing instead on whether the patient in a suspended state is dead or alive. ${ }^{68}$ Harvesting organs from anencephalic infants obviously would provide no difficulty under a regime in which the dead donor rule no longer exists; however, abandonment of the dead donor rule could have dangerous consequences and is unlikely to gain any degree of public support.

An outright abandonment of the dead donor rule seems unlikely in light of the fact that the "standard view" is that all human beings have the right to life exactly because they are living human beings and therefore have full moral status." Therefore, "[t]laking organs would, on this view, be taking the life of a human being." ${ }^{\circ 9}$ It appears that most people believe that harvesting organs before death is immoral and would find any attempt to abandon the dead donor rule undesirable. ${ }^{70}$ Abandonment of this rule might even pose purely pragmatic problems, as it would likely discourage some people from becoming organ donors. ${ }^{71}$ The dead donor rule, despite its potentially sweeping breadth, provides a desirable safeguard in favor of protecting human life. Any efforts made to gain widespread acceptance for harvesting organs from anencephalic infants should not try to undermine the dead donor rule entirely. Instead, any proposed change to the law should engage the rule according to its own terms to show that the dead donor rule should not be considered violated by the act of harvesting organs from anencephalic infants.

\section{B. Argument That Anencephalic Children Never Possess Life}

Some argue that anencephalic children do not qualify as alive, but are instead non-persons, and that the dead donor rule should therefore not apply to them. ${ }^{72}$ Those advocating such an approach would modify the dead donor rule

at www.ccmjournal.com/pt/re/ccm/abstract.00003246-200309000-00019.htm.

67. Norman Fost, Reconsidering the Dead Donor Rule: Is It Important that Organ Donors be Dead?, 14.3 KENNEDY INST. ETHICS J. 249, 249-51 (2004).

68. Koppelman, supra note 47, at 1.

69. Ari Robin Joffe, The Neurological Determination of Death: What Does It Really Mean?, 23 IssUES L. \& MED. 119, 138 (2007).

70. See generally M. Potts \& D.W. Evans, Does It Matter That Organ Donors Are Not Dead? Ethical and Policy Implications, 31 J. MED. ETHICs 406 (2005) (arguing that brain death is not death and that removal of organs from living, but comatose, patients is immoral, as it kills patients, and contrary to the nature of medical practice).

71. See Jerry Menikoff, The Importance of Being Dead: Non-Heart-Beating Organ Donation, 18 IssuES L. \& MED. 3, 12 (2002) (postulating that if the dead donor rule were abandoned, some potential donors might refrain from becoming donors due to fear that doctors would be overeager to use their organs for transplants while they were still alive).

72. This approach is sometimes rephrased to indicate that anencephalic infants, though alive, have no interest in life due to their lack of consciousness and that they should therefore be exempted from the dead donor rule, as their protection does not further its purposes. The two 
to render it "true by definition," retaining the dead donor rule but increasing the categories of patients considered dead to include those, such as anencephalic infants, without higher brain function. ${ }^{73}$ According to this view, "the relevant brain functions for defining life are higher- level consciousness and cognition," so that "[h]umans who lack the capacity for brain function, either because of congenital defect or subsequent brain death, illustrate that a capacity for brain function is necessary for legal life and therefore legal personhood."74 Under such a view, anencephalic neonates do not possess life, or even potential life, and do not require life's attendant legal protections, because "[a]ll rights enumerated in the Constitution and the Bill of Rights are predicated on consciousness, or the capacity for consciousness, except for the right to life itself, which becomes meaningless when consciousness can never exist."75 This view classifies anencephalic infants as not alive, and never having been alive despite their heartbeat, ${ }^{76}$ due to their lack of existing consciousness and capacity for future consciousness. Therefore, doctors may, under such a regime, freely use anencephalic infants as organ sources without fear of violating the dead donor rule.

A regime declaring anencephalic infants to be deceased from conception poses many difficulties, and seems unlikely to gain any degree of general acceptance. In several instances, courts have made it clear they do not view anencephalic infants as legally dead from the outset of their existence despite recognizing that anencephalic children do not possess consciousness. In In re T.A.C.P., the Supreme Court of Florida found "no basis to expand the common law to equate anencephaly with death," despite explicitly recognizing that anencephalic infants lack consciousness and, according to general medical opinion, the capacity to suffer. ${ }^{77}$ Similarly, in In re Baby $K$, the Fourth Circuit Court of Appeals refused to treat an anencephalic child as dead, despite her

statements have the same result, but refusal to deem such infants to be without life seems less cold and more consistent with the general public's view regarding such infants. See Council on Ethical and Judicial Affairs, Am. Med. Ass'n, supra note 29, at 1615 (referring to such infants as alive, but lacking any interest in life due to their lack of consciousness).

73. See Robert M. Veatch, Abandon the Dead Donor Rule or Change the Definition of Death?, 14.3 KENNEDY INST. ETHICS J. 261, 262-66 (noting public perception of death differs from usual assumptions behind dead donor rule, and that sizeable minority of individuals polled would act inconsistently with dead donor rule altogether under its current definition). See also Robert M. Veatch, The Dead Donor Rule: True by Definition, 3 AM. J. BIOETHICs 10, 10-11 (2003) (defending the dead donor rule but arguing in favor of expanding the definition of death).

74. Bennett, supra note 52, at 369-70. See generally Jessica Berg, Of Elephants and Embryos: A Proposed Framework for Legal Personhood, 59 HASTINGS L.J. 369 (2007) (noting that legal or juridical personhood can differ from standard assumptions about personhood and arguing that legal personhood standards may now be more useful than standard definitions of personhood).

75. Ronald E. Cranford \& David Randolph Smith, Consciousness: The Most Critical Moral (Constitutional) Standard for Human Personhood, 13 AM. J.L. \& MED. 233, 247 (1987).

76. Wolfgang Holzgreve et al., Kidney Transplantation from Anencephalic Donors, 316 NEW ENG. J. MED. 960 (1987).

77. In re T.A.C.P., 609 So. $2 \mathrm{~d}$ at 595 (finding that the lack of consensus on the issue of whether or not anecephalic infants are alive outweighed the possibility of saving some infants' lives by allowing organ harvesting from anencephalic infants who do not meet the traditional definition of death). 
complete lack of consciousness, and instead ordered a hospital overriding the hospital's belief that life-sustaining treatment was inappropriate to provide treatment to the anencephalic child at the mother's insistence. ${ }^{78}$ This reluctance to view anencephalic children as non-persons does not stem from mere judicial conservatism; however, as such judicial views draw their force from societal opinion.

Many feel that "any attempt to include anencephalic infants as permissible living organ donors is completely inconsistent with societal mores" because " $[t]$ o redefine infants with anencephaly as being 'born dead' would be tantamount to labeling them as "non-persons," "79 a leap many are unwilling to take. This view derives largely from a general societal concern with respect for life, and is premised on the belief that " $[t]$ o allow removal of the anencephalic infant's vital organs before legal death would allow the active killing of a human being ... [contravening] the current legal prohibition against active killing." Proponents of this view argue that anencephalic infants possess life, and to kill them is infanticide, ${ }^{82}$ whether or not their killers intend their deaths to benefit others.

Society's belief that anencephalic newborns possess life worthy of respect stems from well-entrenched value systems, including conservative approaches to major world religions. ${ }^{83}$ Observation of anencephalic infants can, in certain

78. When Baby $\mathrm{K}$ was born with anencephaly, her doctors put her on a ventilator in order to confirm their diagnosis. Against the doctors' advice, Baby K's mother refused to accept a palliative care regimen, instead insisting on life sustaining care whenever her child had trouble breathing. Baby $\mathrm{K}$ wound up in a nursing home, but occasionally had to be admitted to a hospital to stabilize her breathing. The case arose out of the hospital's eventual attempt to refuse to provide such treatment. The 4th Circuit held for the mother, granting anencephalic Baby $\mathrm{K}$ the same treatment as any other child would get in the circumstances. In re Baby K, 16 F.3d 590, 597-98 (4th Cir. 1994), cert. denied 513 U.S. 825 (1994).

79. Debra H. Berger, The Infant with Anencephaly: Moral and Legal Dilemmas, 5 IssuES L. \& MED. 67, 83-85 (1989).

80. One argument for the inclusion of anencephalic infants within the category of living persons says that, despite the defects stemming from anencephaly, such infants "possess a sufficiently vast amount of human phenotypical traits for one . . . to view them as human children." The argument continues that, as human children, they should be covered by moral principles prohibiting intentional killing. Alfonso Gómez-Lobo, Inviobility at Any Age, 17 KENNEDY INST. ETHICS J. 311,319 (2008).

81. Committee on Bioethics, Infants with Anencephaly as Organ Sources: Ethical Considerations, 89 PEDIATRICS 1116, 1118 (1992).

82. Stephen W. Smith, The Killing of Severely Disabled Newborns: The Spectre Behind the Legislation of Physician Assisted Suicide and Euthanasia, 24 MED. \& L. 791, 796 (2005) (listing anencephalic infants among severely disabled infants likely to be victims of infanticide).

83. See Avraham Steinberg, Medical-Halachic Decisions of Rabbi Shlomo Zalman Auerbach (1910-1995), 3 JEWISH MED. ETHICs 30, 35 (1997) (describing Jewish rabbi's view that taking organs from anencephalic infant while spontaneous respiration continues constitutes murder), available at $\mathrm{http}: / / \mathrm{www}$.medethics.org.il/articles/JME/JMEB2/JMEB2.1.asp\#_ftnref 39; Botkin, supra note 25, at 254 (noting the principle of preserving life at all costs is rooted in Judeo-Christian theology and forbids taking human life, even for benefit of others). See also B. Larijani \& F. Zahidi, Changing Parameters for Abortion in Iran, 14 INDIAN J. MED. ETHICs 130 (2006) (noting Iran, in its enactment of Islamic law, bans abortion after ensoulment, which occurs during pregnancy, which would presumably preclude retrieval of organs from 
situations, reinforce this societal view that such infants possess life in a traditional sense. For instance, despite the lack of higher brain functions, which would enable an infant to process a good or bad taste (or suffering for that matter), some anencephalic infants exhibit responses, including recognizable facial expressions, as a reaction to taste stimuli. ${ }^{84}$ These reactions to stimuli do not necessarily indicate life in a medical sense, yet such realities cause many people to revolt at the idea of deeming anencephalics to be anything less than human. ${ }^{85}$ Society, therefore, would not likely embrace a view that anencephalic infants never possess human life due to their lack of consciousness.

Perhaps the strongest reason for refusing to deem anencephalic infants to be dead in the womb lies in the form of a slippery slope. "The slippery slope is real" and should not be discounted, as some physicians have in the past proposed transplants from infants with defects that fall short of the severity of anencephaly. ${ }^{87}$ These proposals garner any plausibility they might have from the fact that "[s]ome of the arguments for allowing organs to be taken from anencephalic infants apply equally to other permanently unconscious patients, including infants with hydraencephaly and some with microencephaly." ${ }^{, 88}$ Indeed, following the Baby Gabrielle saga, while Loma Linda University was seeking anencephalic infants as sources of organ transplants, some referrals to the program were made by doctors of patients who did not have anencephaly, but rather some lesser malady, including one child who was neurologically intact but lacked functioning kidneys. ${ }^{89}$ This slippery slope could even extend beyond the realm of newborns, potentially reaching those who were once conscious but have since entered a persistent vegetative state, as anencephaly resembles a persistent vegetative state in that " $[\mathrm{b}]$ oth conditions leave affected individuals entirely devoid of cognitive abilities or awareness but with sponta-

anencepahlic infants already birthed).

84. Michael Berger, A Model of Proverbial Social Development and Its Application to Social Dysfunctions in Autism, 47:3 J. CHILD Psychol. \& PsYCHIATRY 338, 339 (2006). These facial indications strike many as indicative of at least some level of life, and this view is supported, albeit in a backhanded way, by the statement that the brain stems of anencephalic infants "do not differ substantially from the brain stem of a fish, [and such infants therefore] have more in common with a fish than a person." Sabra Chartrand, Legal Definition of Death is Questioned in Florida Infant Case, N.Y. TIMES, Mar. 29, 1992, § 1, at 12. As a fish lives, this quote supports the idea that so too do anencephalic infants.

85. See Tom Nolan, .. .And God Will Make Him a Cake, Human LifE ReV., Winter 2007, at 58 (describing a personal encounter with an anencephalic grandchild with the phrase "He was a little boy, not an it").

86. But see Sadath A. Sayeed, The Marginally Viable Newborn: Legal Challenges, Conceptual Inadequacies, and Reasonableness, 34 J.L. MED. \& ETHICs 600, 609 (2006) ("[A]s most practicing physicians know, perhaps unlike some practicing bioethicists, the real moral slope is coated with the thickest molasses in these life and death matters.").

87. Brandon, supra note 32 , at 802.

88. Committee on Bioethics, supra note 79, at 1118 (noting that the argument that anencephalic infants are dead due to lack of consciousness and cognitive capacities reaches to all permanently unconscious patients).

89. D. Alan Shewmon et al., The Use of Anencephalic Infants as Organ Sources, 261 JAMA 1773, 1775 (1989). 
neous cardiac and respiratory functions." 90 Therefore, bioethicists should not disregard the potentially large consequences of failure to heed the slippery slope argument.

Without a clear limiting principle, there is cause for concern with any declaration that anencephalic infants never possess life due to their lack of consciousness from birth and their lack of capacity for consciousness at any point in the future. This slippery slope could even transcend the issue of transplantation, as the eventual solution to the controversy surrounding the use of anencephalic infants as organ sources could have implications for other bioethical and legal debates that generate intense emotion and fierce argumentation. As $\mathbf{R}$. Alta Charo argues, the parties in the abortion debate "search for proxy wars, using debates on research involving human embryos, the donation of organs from anencephalic neonates, and the right of persons in a persistent vegetative state to die as opportunities to rehearse arguments on the value of biologic but nonsentient human existence." 91 Given the possible implications of a wide sweeping announcement that anencephalic infants meet the criteria of being dead prior to birth, a more limited method of justifying the use of anencephalic infants as organ sources seems morally, and less importantly, practically, necessary in light of the dead donor rule.

\section{A Limited Approach Qualifying Anencephalic Infants as an Exception to The Dead Donor Rule}

A more tenable approach towards classifying anencephalic infants in light of the dead donor rule would be to consider them "brain-absent" to a degree sufficient to justify their treatment as brain dead. ${ }^{92}$ This approach, in essence, argues that "because anencephalic infants lack integrated brain function and will inevitably die within a short period of time, they are conceptually very close to being brain dead individuals - close enough to be considered brain dead."93 Such an approach would result in the creation of an entirely new category of brain death filled by anencephalic infants, so that any infant diagnosed as anencephalic, and only those infants diagnosed as anencephalic, would qualify as legally dead under the new category. ${ }^{94}$ Doctors would have little difficulty implementing such a standard since diagnoses of anencephaly are "almost never ambiguous," 95 due to the unique physical manifestations of

90. Barbara Noah, Comment, Politicizing the End of Life: Lessons from the Schiavo Controversy, 59 U. MIAMI L. REV. 107, 109 (2004).

91. R. Alta Charo, The Celestial Fire of Conscience-Refusing to Deliver Medical Care, 352 NEW ENG. J. MED. 2471, 2472 (2005).

92. M.R. Harrison, The Anencephalic Newborn as Organ Donor, HASTINGS CENTER REP., Apr. 1986, at 21-23.

93. Committee on Bioethics, supra note 79, at 1118.

94. See Norman Fost, Removing Organs from Anencephalic Infants: Ethical and Legal Considerations, 16 Clinics IN PERINATOLOGY 331, 334 (1989).

95. Kathleen L. Paliokas, Anencephalic Newborns as Organ Donors: An Assessment of 
anencephaly.

This view acknowledges that anencephalic infants possess life, and therefore does not try to classify them as non-persons. Instead, it recognizes that "[a]ll anencephalics begin to die as soon as they are born." ence between this theory and the theory that anencephalic infants never possess life might seem like mere semantics, there are differences in the resulting implications of the two views. The view that anencephalic infants do possess life, but immediately begin to die at birth, avoids slippery slope pitfalls inherent in the theory classifying the permanently unconscious as dead while remaining more in line with widespread views about personhood than pronouncements that anencephalic infants do not ever possess life. Regardless of whether one views the onset of death as a process, ${ }^{97}$ or an event, ${ }^{98}$ the relevant inquiry for making a determination of death should focus on death as a state, as such a view allows determinations of death to occur in a functional manner that not only is consistent with most religious and philosophical characterizations of death, but that also meets the needs of law and medicine for a definition of death. ${ }^{99}$ Instead of arguing that anencephalic infants never live or lack an interest in life due to their lack of consciousness this view asserts that anencephalic children, though born alive, immediately begin to die, as evidenced by their complete lack of cognitive potentiality and imminent physical death, typically occurring within three days of birth. ${ }^{100}$ Thus, they enter a state of death as soon as they enter the world. ${ }^{101}$ This view does not attempt to deny the personhood of anencephalic infants, which would be hard to justify in light of the heartfelt views of many that such infants are persons. Yet at the same time, this view satisfies the requirements of the dead donor rule, ${ }^{102}$ thereby ensuring that the valuable organs of these small donors do not remain permanently off-limits. ${ }^{103}$

"Death" and Legislative Policy, 31 WM. \& MARY L. REV. 197, 200 (1989).

96. Id.

97. See Baruch A. Brody, How Much of the Brain Must Be Dead?, in THE DEFINTIION OF DEATH: CONTEMPORARY CONTROVERSIES 71 (Stuart J. Younger et. al. eds., 1999) (defending the view that death occurs as a process).

98. See J.L. Bernat, C.M. Culver \& B. Gert, On the Definition and Criterion of Death, 94 ANNALS INTERNAL MED. 389 (1981) (expressing the view that death occurs as an event).

99. James M. DuBois, Is Organ Procurement Causing the Death of Patients?, 18 IssuES L. \& MED. 21, 23 (2002).

100. See Alasdair G.W. Hunter, Brain and Spinal Cord, in Human MALFORMATIONS AND Related ANOMAlies 715, 737 (Roger E. Stevenson \& Judith G. Hall eds., Oxford Univ. Press 2005) (noting that fifty-eight percent of anencephalic children born alive suffer physical death within three days of birth).

101. Committee on Bioethics, supra note 79, at 1118.

102. See Dubois, supra note 50, at 204 ("The key question that should be asked before organ procurement is, 'Is this body in a state of death?' If the body is in such a state, then the question of killing via organ procurement is moot, because killing involves causing someone to enter the state of death.").

103. I merely argue here that such a position appears more likely than available alternative approaches to both define anencephalic infants as dead and accord them the personhood status to which most of society feels they are entitled. Undoubtedly, there will be critics who will argue in favor of maintaining the brightline definition of death embodied in current law and will likely state that a "dying person is still alive" and that a "prediction that death will occur soon is 
An approach centered on the brain absence and imminent physical death of anencephalic infants avoids the slippery slope concerns inherent in a broadsweeping declaration that anencephalic infants, due to their lack of potential for consciousness, never qualify as alive in the first instance. If the medical profession or law begins to treat anencephalic infants as inherently devoid of life, the fear is that "doctors, legislators, or the courts could use the same rationale to declare others dead for the same purposes, including persons in a persistent vegetative state and possibly infants with other severe birth defects." 104 Under a more limited approach focused on the specifics of anencephaly, this fear is not present. As the permanently unconscious, whether through defect or through injury, do not face imminent bodily or cellular death, they would not qualify as brain dead under an approach that focused on the unique aspects of anencephaly, namely lack of potentiality for consciousness and imminent physical death soon after birth, in classifying such individuals as in a state of death. ${ }^{105}$ Therefore, the limited approach cuts off the slippery slope before it can start sliding. In addition to avoiding today's slippery slopes, a legal framework for anencephalic organ transplantation should also address the potential problems imposed by tomorrow's scientific developments.

\section{THE FEAR THAT SCIENTISTS WOULD INTENTIONALLY CREATE ANENCEPHALIC ORGAN DONORS}

\section{A. Scientists May Soon Possess the Ability to Intentionally Create Anence- phalic Infants}

Any regime set up to allow organ donation from anencephalic infants must address not only the bioethical concerns obvious today, but also those concerns that will likely be raised by technological developments in the future. While it might sound like science fiction, the basic technology to intentionally create anencephalic organ donors has already been developed--the question is whether scientists will attempt to perfect it for human application. Scientists have identified the genes responsible for neural tube defects, including exencephaly, a condition in mice roughly equivalent to human anencephaly. ${ }^{106}$ Taking these findings a step further, researchers at the University of Texas successfully created headless mice, whose bodies were otherwise correctly formed, by eli-

not the same as being already dead." Paul A. Byrne et al., Anencephaly-Organ Transplantation?, 9 IssuES L. \& MED. 23, 33 (1993). The case of the anencephalic infant, however, does not fit so neatly into current concepts of death, a fact which would be of little importance, but for the issue of transplantation.

104. Justice, supra note 46 , at 1264.

105. R.D. Truog \& J.C. Fletcher, Anencephalic Newborns: Can Organs Be Transplanted Before Brain Death?, 321 NEw ENG. J. MED. 388, 388-91 (1989).

106. See generally Diana M. Jurloff \& Murlel J. Harris, Mouse Models for Neural Tube Closure Defects, 9.6 HuMAN MOLECULAR GENETICs 993 (2000) (relaying findings indicating responsibility of particular genes for neural tube defects in mice and indicating that genes identified in mice with neural tube defects have potential homologues in humans). 
minating a particular gene, known as Lim1, from the embryonic stem cells of the mice. ${ }^{107}$ As the gene in question belongs to the homeobox group of genes, which are "essential for embryonic development" and "present in all animals," 108 this discovery possesses a potentially vast, inter-species reach. ${ }^{109}$ In other words, just as the cloning of the sheep "Dolly" revealed to the public that the trajectory of cloning technology was not far from intentionally cloning humans, such is the moment with developmental biology.

Not long after scientists demonstrated the ability to intentionally create these headless animals, they began to theorize that, "[b]ecause the genetic mechanisms that control [animal] development are very similar to those that lay down the human body plan it will be possible "to suppress the development of the [human] embryo."110 Some have long hoped for similar possibilities, that after suppression or modification of the proper genes, a human fetus "could then be grown as a brain-dead body for spare parts." "111 Due to its lack of a capacity for consciousness, the brain-dead human fetus would potentially be unable to suffer harm. ${ }^{112}$ These creatures would in essence be "cannibalized for spare parts." 113

Some celebrate the development of headless animals, for if such techniques were perfected to create headless humans, many of the factors that inherently limit the efficacy of anencephalic organ donation would disappear in the face of a potentially abundant supply of intentionally created anencephalic organ donors. ${ }^{114}$ Indeed, one of the requirements for creating a successful transplant program is repetition, which requires a sufficient volume of cases. This is why larger transplant centers, such as the Mayo Clinic, have better transplant success rates than smaller, regional programs. ${ }^{115}$ A larger supply of anence-

107. See W.W. Shawlot \& R.R. Behringer, Requirement for Lim1 in Head-Organizer Function, 374 NATURE 425 (1995) (finding the gene Liml to be the essential regulator of the organization of the vertebrate head).

108. Lori Olwenstein, Headless: Lacking a Single Gene, Mice Are Born Without Heads, DisCOVER, Jan. 1, 1996, available at http://discovermagazine.com/1996/jan/headless658.

109. See Jonathan Slack, Headless Tadpoles \& an Informed Public, 390 NATURE 111 (1997) (describing the British researcher who corrects misunderstandings of his own work which involves creation of headless tadpoles through the manipulation of genes).

110. Roger Highfield, Patient's Clones 'May Grow Transplant Organs,' THE DAILY TELEGRAPH, Oct. 20, 1997, available at http://www.telegraph.co.uk/htmlContent.jhtml?html $=/$ archive/1997/10/20/nclo20.html.

111. Carol Kahn, Can We Achieve Immortality? The Ethics of Cloning and Other Life Extension Technologies, FREE INQUIRY, Spring 1989, at 14-18.

112. David W. Brock, Cloning Human Beings: An Assessment of the Ethical Issues Pro and Con, in NAT'L BIOETHICS AdVISORY COMM'N, 2 ClonING HuMAN BEINGS E4, E8 (1997). 65.

113. Philip Elmer-Dewitt, Cloning: Where Do We Draw the Line?, TIME, Nov. 8, 1993, at

114. See D. Alan Shewmon et al., The Use of Anencephalic Infants as Organ Sources, 261 J. AM. MED. Ass'N. 1773, 1774-75 (1989) (estimating that donation from naturally occurring anencephalic infants would produce only eleven usable organs per year in the United States due to the premature nature of most anencephalic births, low success rate of neonatal transplants, and logistical difficulties in the transplant network).

115. See Transplant Programs at MAYO Clinic, available at http://www.mayoclinic 
phalic donor organs should logically lead to better success from this particular source. ${ }^{116}$ Additionally, some thinkers state that many of the donation consent problems inherent in today's transplant donor sources, such as truly "informed consent" and familial coercion, could be avoided in situations involving intentionally created anencephalic organ donors. ${ }^{117}$ The presumption being, a headless organ donor would not have an interest in life necessitating consent to organ donation. Further, the donor's parents would have presumably consented to its creation for transplant purposes. ${ }^{118}$ The argument is that once one accepts the ethical reasoning in support of allowing organ donation from anencephalic infants, it is a small leap along the same logical path to accept the ethical propriety of allowing organ procurement from donor children intentionally created to be anencephalic. ${ }^{19}$

Neoconservative pundit Charles Krauthammer dismays at the potential creation of headless human beings to be used as organ donors, as such an initiative would reduce "the human embryo to nothing more than a manufactured thing ...." ${ }^{20}$ Such an action would thereby violate the Kantian imperative to treat each person as an end in themselves, not a means to someone else's end. ${ }^{121}$ Those seeking to temper this response point out that mankind does not yet have the ability to create headless human organ donors and that "[w]hether the technologies that have stirred public fears will ever become a reality is hard to say." ${ }^{122}$ By pairing human cloning and artificial reproduction technology, however, it is not difficult to imagine a research protocol for perfecting this technology. Yet, many Americans who would not otherwise oppose scientific research into stem cells, cloning, and gene manipulation technology, would likely be put off by these endeavors, in addition to anencephalic organ donation, if the specter of intentionally creating anencephalic organ donors lurked in the shadows.

Those taking this position agree with Krauthammer's statement, made in

.org/transplant. "Mayo Clinic doctors perform more than 1,100 transplants a year, making it the largest transplant program in the United States." Id.

116. See Richard J. Howard, The Challenging Triangle: Balancing Outcomes, Transplant Numbers and Costs, 7 AM. J. TRANSPLANTION 2443 (2007) ("Transplant centers juggle at least three objectives important to success: transplant volume, outcomes and costs.")

117. Laura J. Hilmert, Cloning Human Organs: Potential Sources and Property Implications, 77 IND. L.J. 363, 369-70 (2002).

118. Id.

119. Shannon H. Smith, Ignorance Is Not Bliss: Why a Ban on Human Cloning Is Unacceptable, 9 HEALTH MATRIX 311, 331 (1999) (noting that the utilitarian argument in favor of anencephalic organ transplantation may be even stronger in cases involving intentionally created anencephalic infants).

120. Charles Krauthammer, Cloning Debate Is Not Another Monkey Trial, WASH. PosT, May 10, 2002, available at http://www.townhall.com/columnists/CharlesKrauthammer/2002/ 05/10/cloning_debate_is_not_another_monkey_trial.

121. Charles Krauthammer, Of Headless Mice... and Men, TIME, Jan. 19, 1998, available at: http://www.time.com/time/magazine/article/0,9171,987687,00.html.

122. Oliver Morton \& Nigel Williams, First Dolly, Now Headless Tadpoles, 278 SCIENCE 798 (1997). See also Robert Pool, Saviors, Discover, May 1, 1998, available at http://discovermagazine.com/1998/may/saviors1442 (arguing that science will have less difficulty growing individual organs than growing headless organ donors in laboratories). 
response to proposals for the allowance of embryonic cloning for research purposes, but applicable in the present context, that "[t]his is not a slide down the slippery slope ... [t] this is downhill skiing." 123

Since the intentional creation of anencephalic organ donors transgresses the Kantian injunction internalized by many Americans, it is difficult to imagine such actions receiving legal protections at either the state or federal level any time soon. Therefore, the fear of anencephalic infants being intentionally created to serve as organ sources stands as a potential roadblock to the effective use of naturally born anencephalic infants as organ donors, in addition to other potentially beneficial channels of scientific inquiry. Any legal framework designed to reap the benefits of anencephalic organ donation must therefore be carefully tailored so as to ensure that anencephalic organ donation rests on solid ground, safe from the slippery slope of anencephalic infants "on demand" for transplant purposes. A legal regime allowing for anencephalic organ donation should include provisions attacking the producers of intentionally created anencephalic organ donors and those doctors unscrupulous enough to use organs from intentionally created anencephalic humans in transplant procedures.

\section{B. Proposed Legal Rules to Ensure the Integrity of the Anencephalic Organ Transplant Process}

\section{Criminalization of Intentional Creation of Anencephalic Human Beings}

In order to ensure that scientists do not use emerging gene suppression technology to create an endless supply of artificially created anencephalic organ donors, lawmakers must impose criminal sanctions on anyone engaged in the intentional creation of anencephalic infants. Such a measure would effectively eliminate, or at least reduce, the stream of artificially created anencephalic donor organs at its source. Current law and medical association guidelines do not directly address the intentional creation of anencephalic infants, although they have addressed similar bioethical issues, such as human cloning.

As scholars have analogized the use of anencephalic organ donors to the possibility of using body clones for transplant purposes, ${ }^{124}$ statutory or organizational bans on human cloning might influence the structure and rationale of a ban on the intentional creation of anencephalic organ donors. The medical community, acting through medical associations, has refused to go beyond expressing opposition to reproductive cloning and advising medical professionals to obey the laws of the nations in which they practice governing therapeutic

123. Charles Krauthammer, Cloning Debate Is Not Another Monkey Trial, WASH. Post, May 10, 2002, available at $\mathrm{http}: / / \mathrm{www}$.townhall.com/colunists/CharlesKrauthammer/2002/ 05/10/cloning_debate_is_not_another_monkey_trial..

124. See Shannon H. Smith, Note, Ignorance Is Not Bliss: Why a Ban on Human Cloning Is Unacceptable, 9 HEALTH MATRIX 311, 329 (1999) (noting that, like anencephalic infants, body clones might lack the ability to be harmed due to the lack of capacity for consciousness). 
cloning. ${ }^{125}$ Some argue that forms of therapeutic cloning are morally indistinguishable from the deliberate creation of an anencephalic human being., ${ }^{126}$ It seems unlikely that medical associations will lead the charge to condemn or punish the intentional creation of anencephalic infants for use as transplant donors. Legislatures must take charge in prohibiting the intentional creation of anencephalic organ donors, much as they have taken a leading role in condemning, regulating, and often criminalizing various forms of human cloning. ${ }^{127}$

Internationally, the issue of cloning creates huge controversy and concern, as indicated by the strange alliances and position shifts that occurred during the debate over the issue in the United Nations ("UN"). ${ }^{128}$ The UN eventually settled on a non-binding call for a qualified ban on human cloning. ${ }^{129}$ It seems unlikely, however, that the UN Declaration on Human Cloning has put the issue to rest given the stark differences in opinion expressed by different member-nations during the UN debate. ${ }^{130}$ While the legislative bodies in the United States have not addressed the intentional creation of anencephalic infants, they have taken positions on human cloning technology.

Several state legislatures have banned human cloning, often imposing criminal sanctions on those engaged in the practice. ${ }^{131}$ Such regulations demonstrate the willingness of American legislatures to address bioethical issues, ${ }^{132}$

125. See American Medical Association, Policy E2.147: Cloning to Produce CHILDREN (2003), available at http://www.ama-assn.org/apps/pf new/pf_online?f_n=result

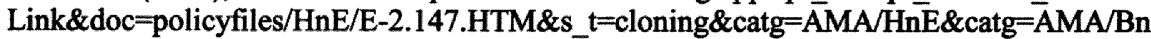
GnC\&catg=AMA/DIR\&\&nth=1\&\&st $p=0$ \&nth $=3$ \& (urging medical professionals not to pursue "cloning-to-produce-children at this time," which presumably would include artificially created anencephalic children); WORLD MEDICAL ASSOCIATION, THE WORLD MEDICAL ASSOCIATION STATEMENT ON GENETICS AND MEDICINE (2005), available at http://www.wma. net/e/policy/g11.htm (opposing reproductive cloning, noting reproductive cloning is considered in many countries "to pose more of an ethical problem than therapeutic cloning" and urging medical professionals to obey codes of medical ethics in their countries regarding cloning).

126. Ronald M. Green, Can We Develop Ethically Universal Stem Cell Lines, 8 NATURE REVIEWS GENETICS 480, 481 (2007).

127. See infra notes $126-128$ and accompanying text.

128. See generally Nigel M. de S. Cameron \& Anna V. Henderson, Brave New World at the General Assembly: The United Nations Declaration on Human Cloning, 9 MiNN. J.L. SCI. \& TECH. 145 (2008) (discussing debates between and position shifts of UN member- nations regarding UN Declaration on Human Cloning).

129. UNITED NATIONS GENERAL ASSEMBLY, UNITED NATIONS DEClaRATION ON HuMAN CLONING (Mar. 23, 2005) (calling on UN member-states "to prohibit all forms of human cloning in as much as they are incompatible with human dignity and the protection of human life").

130. See U.N. Press Release, General Assembly Adopts United Nations Declaration on Human Cloning by Vote of 84-34-37 (Aug. 3, 2005), available at, http://www.un.org/News/ Press/docs/2005/ga10333.doc.htm.

131. See, e.g., ARK. Code ANN. § 20-16-1002 (2003); Cal. Health \& SAFETy Code $\S$ 24185 (2003); 410 ILL. COMP. STAT. ANN. 110/40(WEST 2008); IND. CODE § 35-46-5-2 (2006); MiCH. COMP. LAWS § 750.430a (1999); N.J. STAT. ANN. § 2C:11A-1 (2004); N.D. CENT. CODE § 12.1-39-02 (2007); R.I. GEN. LAWS $§ 23-16.4-2$ (1998); S.D. CoDIFIED LAWS $§ 34-14-27$ (2004); VA. CODE ANN. § 32.1-162.22 (2001).

132. But see CHICAGo-Kent COLlege of LAW Institute FOR SCIENCE, LAW, AND TECHNOLOGY, The Laws of Reproductive Technology, available at http://www.kentlaw.edu/ islat/reprotech.html (asserting that lawmakers have responded slowly to cloning and related 
a trend which logically should extend as science makes the deliberate creation of anencephalic children clinically, if not politically, more feasible. Additionally, these anti-cloning laws already cover the possibility of creating human clones, including anencephalic clones, for the purpose of creating the perfectly matched organ donor. ${ }^{133}$ Nevertheless, these anti-cloning regulations do not create national uniformity and do not cover the possibility that scientists might intentionally create non-clone anencephalic infants to serve as transplant organ reservoirs. Therefore, new legislation is required.

Legislatures should take action to prohibit the intentional creation of anencephalic human beings. In particular, legislatures should not assume that parents will universally reject creating anencephalic organ donors should such technology become available. Past incidents in which parents have used scientific developments in assisted reproduction to create organ donors for previously conceived siblings ${ }^{134}$ vividly illustrates that any reliance on parents abstaining from creating another life as a means to save an existing child is sorely misplaced. Desperate situations lead people, including parents and doctors, ${ }^{135}$ to do desperate things. ${ }^{136}$ Thus, given the current state, the law must anticipate and address valid concerns regarding the deliberate creation of anencephalic infants.

To enable anencephalic organ donation in general to become legally and medically acceptable, legislative action is needed to properly circumscribe the particular practice of intentionally creating anencephalic children. It would be necessary to attack the sources of manufactured anencephalic donor organs in a couple of ways. Specifically criminalizing the intentional creation of anencephalic human beings is an obvious first step. Congress must pass such a statute in order to ensure uniformity in its application across the United States. ${ }^{137}$ This

technologies).

133. See George W. Miller, Moral and Ethical Implications of Human Organ TRANSPLANTS 71 (1971) (explaining that risk of rejection declines when organs from an exact genetic match are transplanted into recipient).

134. See Jacqueline Brooks, Sibling Selection, WeBMD, June 26, 2001, available at http://www.webmd.com/news/20010626/sibling-selection (describing parents' decision to undergo in- vitro fertilization to create a baby boy who donated umbilical cord blood to his sister with a rare, incurable disease). See also Curran v. Bosze, 141 Ill.2d 473 (1990) (holding that a father could not compel his minor twins to submit to bone marrow harvesting for the sake of their half-brother, who was the father's son by a different woman).

135. See Rob Stein, New Practices In Organ Donation Inspire Debate, SAN Francisco CHRONICLE, March 19, 2007, at A-5 (noting that doctors already bend existing rules by beginning the organ harvesting process soon after a patient ceases to breath).

136. The case of the "Pillow Angel" caused quite a stir in both medical journals and the tabloid press. This case involved Ashley, a severely mentally and physically disabled six-yearold girl that intentionally had her growth halted by hormones, and had her uterus and breast buds removed by doctors at the request of her parents. The parents stated on a blog, "Ashley's smaller and lighter size makes it more possible to include her in the typical family life and activities that provide her with needed comfort, closeness, security and love: meal time, car trips, touch, snuggles, etc." See Nancy Gibbs, Pillow Angel Ethics, TIME, Jan. 22, 2007, available at $\mathrm{http}: / / \mathrm{www}$. time.com/time/ $0,8816,1574851,00 . \mathrm{html}$.

137. See Louise Weinberg, Fear and Federalism, 23 OHо N.U.L. REv. 1295, 1317 (1997) (listing "need for uniformity" among concerns that qualify as "national interests" often used to 
will also help avoid the creation of a medical tourism industry within America in which states that choose not to impose criminal penalties on the intentional creation of anencephalic organ donors would beckon transplant recipients from other states. ${ }^{138}$ Such a law would take the decision about whether to intentionally create an anencephalic infant out of the hands of doctors and desperate parents, as while "[ $p]$ arents may be free to become martyrs themselves ... it does not follow that they are free, in identical circumstances, to make martyrs of their children, ${ }^{, 139}$ including those children who might one day be intentionally programmed to develop as anencephalic through genetic manipulation. Imposing criminal sanctions on those intentionally creating anencephalic children will reduce the supply of such organs, but to ensure the integrity of a system legalizing anencephalic organ donation, legislatures must also address the possibility that doctors turning a blind eye to the source of donor organs might use organs from intentionally created anencephalic organ donors in transplants.

\section{Imposition of Strict Liability for Anyone Transplanting Organs From In- tentionally Created Anencephalic Infants}

While criminalizing the intentional creation of anencephalic organ donors will presumably deter some would-be producers of anencephalic transplant organs, that measure alone will not effectively control the black market almost certain to develop if the legalization of anencephalic organ donation coincides with the development of the technology to intentionally create anencephalic humans. ${ }^{140}$ We have already seen sophisticated black markets for the selling of kidneys from live donors arise, with some of the donors knowingly selling their organs, and others being coerced into doing so. ${ }^{141}$ A regime allowing for anencephalic organ donation must provide strong ex ante disincentives for transplant physicians and clinics to use organs harvested from clinically manufactured anencephalic infants. Ergo, Congress must, in addition to criminalizing the intentional creation of anencephalic humans, impose strict criminal liability on any person transplanting organs from intentionally created anencephalic hu-

justify taking certain issues out of the hands of states).

138. Congress could presumably pass such a law under its Commerce Clause powers, as evidenced by the Supreme Court's holding that prohibiting the intrastate possession or manufacture of an article of commerce, including items for which the only commercial market is illegal, is a rational means of regulating commerce in that product. Gonzales v. Raich, 545 U.S 1 (2004). See also Wickard v. Fillburn, 317 U.S. 111 (1941) (allowing Congress to ban, under the Commerce Clause power, production of a small quantity of wheat for personal consumption and use).

139. Strunk v. Strunk, 445 S.W.2d 145, 150 (Ky. 1969) (Steinfeld, J., dissenting).

140. See Michelle Goodwin, Altruism's Limits: Law, Capacity, and Organ Commodification, 56 RUTGERS L. REV. 305 (2004) (detailing private organ sales and black markets in organs driven by patients seeking alternatives to an overloaded altruistic organ donation system).

141. See Anuj Chopra, Organ-Transplant Black Market Thrives in India, S.F. CHRONICLE, Feb. 9, 2008 available at http://www.sfgate.com/cgi-bin/article.cgi?f=/c/a/ 2008/02/09/MN23UPQ0K.DTL. 
mans.

A strict liability crime "does not require a mens rea element", so that the mere commission of the criminal act itself, regardless of the motive of the person committing the act, results in criminal punishment. ${ }^{142}$ The imposition of strict liability on physicians and clinics that transplant organs from intentionally created anencephalic humans ensures that unscrupulous or careless physicians do not turn a blind eye to the source of their organs and keeps the difficult task of proving a physician's knowledge or intent from undermining the integrity of the anencephalic donor system. ${ }^{143}$ Under such a statute, these medical professionals cannot avoid criminal penalties by claiming that they were unaware of the source of the donor organs used in their transplants.

The proposed strict liability regime incentivizes medical professionals to ask questions about the source of their organs. These professionals, due to the threat of strict liability, will in effect support the law proposed above-criminalizing the intentional creation of anencephalic humans - by refusing to participate in a market for donor organs from intentionally created anencephalic infants and verifying the sources of donor organs offered for use in their practices in order to protect their own professional interests. In effect, criminalizing the willful creation of anencephalic infants and imposing strict liability on physicians and clinics using transplant organs from this source will mutually reinforce each other: physicians will respond to the threat of liability by investigating organ sources, thus reducing economic incentives to create anencephalic transplant donors.

The United Network for Organ Sharing ("UNOS") would likely play a major role in this regime, administratively tracking whether banned organs are being used. This organization already "monitors every organ match to ensure adherence to UNOS policy, and works . . . to develop equitable policies that maximize the limited supply of organs." "144 Therefore, UNOS already possesses the capabilities to track and audit organs obtained from anencephalic infants. For instance, upon detecting a statistical spike in the number of anencephalic organs used in transplant procedures conducted by a particular medical professional, a particular clinic, or in a particular region, UNOS could initiate an investigation. Having legally represented a transplant center that was officially reviewed by UNOS for allegedly "upcoding" liver transplant patients, it is clear that UNOS possesses significant power to investigate and regulate transplant physicians and programs and can effectively shut down a transplant program by restricting access to organs procured through its national network. ${ }^{145}$ However,

142. BLACK's LAW DiCTIONARY (8th ed. 2004) (listing definition under "crime").

143. See A.P. SimESTER, APPRAISING STRICT LiABILITY 25-33 (A.P. Simester ed., Oxford University Press) (2005) (listing cost-effectiveness, administrative convenience, and difficulties of proof among rationales for imposing strict liability for criminal offenses).

144. United Network for Organ Sharing, What We Do, available at http://www.unos.org/whatWeDo.

145. Author Fazal Khan legally represented a large urban transplant center that was under UNOS investigation from 1995-1998. This investigation was taken very seriously by the 
being a non-profit, private organization, UNOS does not have the legal authority to impose criminal or civil sanctions. Yet, the information gathered by UNOS can serve as a predicate to trigger state and federal criminal investigations. With the strict liability regime described in this subsection, transplant doctors and programs would have a strong incentive to investigate their organ providers, thus reinforcing the intended effect of criminal penalties for willfully creating anencephalic humans.

Congress should strongly consider this proposed legislation because the possible intentional creation of anencephalic organ donors, like human cloning, is "a matter far too important to be left solely in the hands of the scientific and medical communities." human creation is not simply a matter of scientific inquiry [but] a matter of morality and spirituality as well."147 For medical culture and general society to accept a framework that allows anencephalic organ donation to occur, it is a desideratum that lawmakers address legitimate moral concerns regarding the intentional creation of anencephalic human beings for use as organ donors. Legislatures can best accomplish this through the criminal law, as, in the view of the majority of people, the intentional creation of anencephalic humans would be a grave moral violation, and "[c]rimes are the sorts of serious wrongs that merit state punishment of the wrongdoer."148 By criminalizing the intentional creation of anencephalic infants and imposing strict liability on physicians and clinics using organs from intentionally created anencephalic infants in transplant procedures, Congress would ensure that society could enjoy the benefits of anencephalic organ donation without fear of the slippery slope. In particular, the allowance of the practice could lead to a brave new world in which scientists literally farm humans deliberately rendered anencephalic to serve as organ donors.

\section{A POSSIBLE SOCIOECONOMIC IMPLICATION OF ANENCEPHALIC ORGAN DONATION}

The allowance of organ harvesting from anencephalic infants, even if properly limited under a tight legal framework, could lead to unforeseen consequences. One area of particular concern arises out of the disparity in "the ability of members of different socioeconomic classes to benefit from such technology."149 The possibility exists that, should anencephalic organ donation

transplant program as they knew UNOS had the power to severely limit their transplant activities. The transplant program, however, was also aware that UNOS did not have the authority to impose criminal or civil sanctions. See Press Release, U.S. Dep't Justice, UIC Med. Ctr. Pays \$2 Million to U.S. and State of Ill. to Settle Liver Transplant Fraud Suit (Nov. 17, 2003) (available at http://www.usdoj.gov/usao/iln/pr/chicago/2003/pr111703_01.pdf).

146. James D. Watson, Moving Toward the Clonal Man, AtLANTIC, May 1971, at 50.

147. Bill Clinton, Remarks by President Clinton on Cloning (Mar. 4, 1997) (Transcript available at 1997 WL 571115).

148. Grant Lamond, What Is a Crime?, 27 Oxford J. Legal StUd. 609, 631 (2007).

149. Sandra Anderson Garcia, Sociocultural and Legal Implications of Creating and 
be legally permitted, the practice could benefit children in society's higher socioeconomic classes at the expense of those in lower socioeconomic classes.

Several factors render poor mothers more likely to give birth to children with anencephaly than their more economically advantaged counterparts. ${ }^{150}$ On the most obvious level, want of basic nutrition increases the incidence rates of birth defects of many varieties, ${ }^{151}$ a fact that bears more heavily on the poor than the rich due to lack of resources. Similarly, while folic acid supplementation has proven to be a successful technique in the fight to prevent anencephaly, ${ }^{152}$ "[w]omen who were non-white, were aged 18-24 years, had less than a high school education, or had a household income of [less than] $\$ 25,000$ were the least likely to report daily consumption of a supplement containing folic acid" in a recent study conducted by the Center for Disease Control. ${ }^{153}$ Finally, environmental exposure to toxins, a plight which overwhelmingly affects the poor, can drastically increase the likelihood of neural tube defects such as anencephaly. ${ }^{154}$

While poor women face an increased risk of anencephalic pregnancy, women from higher socioeconomic classes enjoy the benefits of increased prevalence of prenatal screening and ease of access to abortion, which, in tandem, render women from society's upper echelons much less likely than poor women to actually bring to term a fetus suffering from a genetic defect as serious as anencephaly. ${ }^{155}$ One possible effect of this dynamic could be that, should anencephalic organ harvesting be permitted, the organs of anencephalic children of poor families willing to donate the organs of their children could be used to improve the lives of children of rich parents with access to high quality med-

Sustaining Life Through Biomedical Technology, 17 J. LEGAL MED. 469, 473 (1996).

150. See Birgitte M. Blatter et al., Review of Neural Tube Defects: Risk Factors in Parental Occupation and the Environment, 102:2 ENVTL. HeALTH PERSP. 140, 141 (1994) (noting that across societies and racial groups, the prevalence of anencephaly increases as socioeconomic status decreases). See also Yang et al., Socioeconomic Status in Relation to Selected Birth Defects in a Large Multicentered US Case-Control Study, 167:2 AM. J. EPIDEMIOL. 145, 150 (2008) (noting that an international trend also exists within the United States).

151. See generally Susan L. Carmichael et al., Maternal Food Insecurity Is Associated with Increased Risk of Certain Birth Defects, 137:9 J. OF NUTRITION 2087 (noting that lack of access to food in sufficient quantities to meet basic needs increases occurrences of birth defects).

152. See De Wals et al., supra note 9.

153. Centers for Disease Control and Prevention, Use of Supplements Containing Folic Acid Among Women of Childbearing Age-United States, 2007, 57.11 MORBIDITY \& MORTALITY WKLY. REP. 5, 6 (Jan. 11, 2008).

154. See, e.g., Stemp-Morlock, supra note 6, at A78 (linking pesticides to increased incidences of anencephaly among parents who work in agricultural fields); Joshua M. Kagan, Note, Workers' Rights in the Mexican Maquiladora Sector: Collective Bargaining, Women's Rights, and General Human Rights: Law, Norms, and Practice, 15 J. TRANSNAT'L L. \& POL'Y $153,163(2005)$ (observing high rates of anencephaly among industrial workers in factories along the border between the United States and Mexico, presumably due to exposure to the toxin, PCB).

155. See Sonia Mateu Suter, The Routinization of Prenatal Testing, 28 AM. J. L. \& MED. 233,236 (2002) (noting that the rise in prenatal testing coincided with the recognition of a woman's right to an abortion, increasing the ability of women with access to medical care to control their reproductive lives). 
ical care capable of carrying out an infant transplant. This fear could cause some who would otherwise be willing to embrace anencephalic organ donation to instead shy away from the practice due to its possible class consequences.

While concern over the class implications of a policy permitting anencephalic organ donation is legitimate, it should not bar the actual implementation of such a regime. To begin, until such a program is implemented, no one can know how these class concerns will play out in reality. Additionally, the problem, should such concerns come to fruition, would arise not out of the policy permitting anencephalic organ donation, but would rather stem from the disparities in resources between the rich and the poor. The best solutions to these class concerns would attempt to provide poor mothers with greater access to prenatal care ${ }^{156}$ and nutrition, ${ }^{157}$ rather than attempting to ban anencephalic organ donation altogether.

\section{CONCLUSION}

Anencephaly results in swift death for those infants who suffer from it. Even while their bodies live, these infants do not in any way experience the world or even their own existence. Nevertheless, such children possess organs which could be used for transplantation into other children in need of them, ameliorating the effects of the fact that "the demand for organs is far outstripping the supply."158 From a utilitarian perspective, allowing donation of organs from anencephalic infants seems proper as it benefits the recipients of the organs and the families of both the donor and recipient, while burdening the anencephalic donor herself to little or no degree.

Deontological concerns prove more troubling than utilitarian considerations when dealing with anencephalic infant organ transplantation. While it would seem that such infants, when used as donors, are being treated as a means to an end, some unpersuasively counter with the utilitarian argument that allowing organ donations from anencephalic infants respects them "as human beings because they serve a highly worthwhile purpose." 159 A more persuasive response to these Kantian concerns is, however, that anencephalic infants are born immediately into the state of death, due to their imminent physical death and their complete lack of consciousness or the potentiality for consciousness.

156. See Carolyn Jacobs Chachkin, What Potent Blood: Non-Invasive Prenatal Genetic Diagnosis and the Transformation of Modern Prenatal Care, 33 AM. J.L. \& MED. 9, 38 (2007) (arguing that both public and private insurers should cover non-invasive prenatal testing, emerging technology capable of identifying fetal birth defects including anencephaly).

157. See G. Maberly et al., Trends in Wheat Flour-Fortification with Folic Acid and IronWorldwide, 2004 and 2007, http://www.cdc.gov/mmwR/preview/mmwrhtml/mm5701a4.htm (last visited April 4, 2008) (noting that as of 2007, fifty four countries fortify their wheat flour with folic acid). (1995).

158. Fred H. Cate, Human Organ Transplantation: The Role of Law, 20 J. CORP. L. 69, 70

159. Willke \& Andrusko, supra note 44, at 31. 
Such a view avoids the unfavorable consequences of abandoning the dead donor rule altogether and eliminates the slippery slope risks inherent in declaring anencephalic infants to be non-people completely devoid of life due to their permanent lack of consciousness. This approach would legally define anencephalic infants as being born into death. This category, strictly limited to anencephalic infants, would be added to the definitions of death adopted by the Uniform Determination of Death Act, thereby making possible transplantation of the organs of anencephalic infants into newborns needing transplants without violation of the dead donor rule.

Unanswered questions remain as to some of the practical effects of a policy allowing anencephalic infants to serve as organ donors. One of these concerns, the fear that scientists will intentionally create anencephalic organ donors, can be addressed legally, such as by the proposed laws criminalizing the intentional creation of anencephalic humans and imposing strict liability on transplant doctors using organs donated from intentionally created anencephalic infants. Other issues cannot be addressed so simply. For instance, legitimate concerns exist that the allowance of anencephalic organ donation could benefit the children of the rich, who are more likely to have access to exceptional medical care, at the expense of the poor, who remain more likely to give birth to an anencephalic child who might be used as a source of transplant organs. ${ }^{160}$ In addition, it remains questionable how great an impact the allowance of anencephalic organ transplantation will have on the dire predicaments of children in need of organs. ${ }^{161}$ These questions appear unanswerable in the absence of actual acceptance of a policy allowing the harvesting of anencephalic infants' organs for transplantation. These unanswered questions should not delay the implementation of such a policy, as the use of anencephalic organs in transplants is both morally justified and legally advisable. Until those in positions of power deem such a policy permissible, infants born with defects that could be cured through a transplant will continue to die needlessly and the parents of anencephalic infants will continue to be denied a chance to transform their personal tragedy into an altruistic good.

160. See supra notes 104-108 and accompanying text.

161. The number of anencephalic infants actually carried to term is limited, and the availability of abortion and genetic counseling will likely further decrease that number. See Alexander Morgan Capron, Anencephalic Donors: Separate the Dead from the Dying, HASTINGS CENTER REP., Feb. 1987, at 5 (observing that only 2,000 to 3,000 of such babies are born every year, not all of whom will be offered as organ donors by their parents); Frank A. Chervenak, et al., When is Termination of Pregnancy During the Third Trimester Morally Justifiable?, 310 NEW ENG. J. MED. 501, 502 (1984) (noting that in cases of anencephaly, even third trimester abortion is largely considered ethically justifiable). See also DOROTHY C. WERTZ \& JOHN C. FLETCHER, GENETICS AND ETHICS IN GLOBAL PERSPECTIVE 373 (2004) (49\% of United States genetic professionals would counsel for anencephaly in negative fashion, thereby making abortion of such infants more likely). 
